\title{
Spatiotemporal Mapping Reveals Regional Gastrointestinal Dysfunction in $m d x$ Dystrophic Mice Ameliorated by Oral L-arginine Supplementation
}

\author{
Kristy Swiderski, ${ }^{1}$ Rebecka Bindon, ${ }^{1}$ Jennifer Trieu, ${ }^{1}$ Timur Naim, ${ }^{1}$ Shana Schokman, ${ }^{2}$ Mathusi Swaminathan, ${ }^{2}$ \\ Anita J L Leembruggen, ${ }^{2}$ Elisa L Hill-Yardin, ${ }^{2,3}$ René Koopman, ${ }^{1}$ Joel C Bornstein, ${ }^{2}$ and Gordon S Lynch ${ }^{1 *}$ \\ ${ }^{I}$ Centre for Muscle Research, Department of Physiology, School of Biomedical Sciences, The University of Melbourne, Australia; ${ }^{2}$ Enteric \\ Nervous System Laboratory, Department of Physiology, The University of Melbourne, Australia; and ${ }^{3}$ Gut-Brain Axis Laboratory, School of \\ Health and Biomedical Sciences, RMIT University, Melbourne, Australia (Current address)
}

\section{Background/Aims}

Patients with Duchenne muscular dystrophy exhibit significant, ongoing impairments in gastrointestinal (GI) function likely resulting from dysregulated nitric oxide production. Compounds increasing neuronal nitric oxide synthase expression and/or activity could improve GI dysfunction and enhance quality of life for dystrophic patients. We used video imaging and spatiotemporal mapping to identify GI dysfunction in $m d x$ dystrophic mice and determine whether dietary intervention to enhance nitric oxide could alleviate aberrant colonic activity in muscular dystrophy.

\section{Methods}

Four-week-old male C57BL/10 and $m d x$ mice received a specialized diet either with no supplementation (control) or supplemented $(1 \mathrm{~g} / \mathrm{kg} /$ day) with L-alanine, L-arginine, or L-citrulline for 8 weeks. At the conclusion of treatment, mice were sacrificed by cervical dislocation and colon motility examined by spatiotemporal (ST) mapping ex vivo.

\section{Results}

ST mapping identified increased contraction number in the mid and distal colon of $m d x$ mice on control and L-alanine supplemented diets relative to $\mathrm{C} 57 \mathrm{BL} / 10$ mice $(P<0.05)$. Administration of either L-arginine or L-citrulline attenuated contraction number in distal colons of $m d x$ mice relative to $C 57 B L / 10$ mice.

\section{Conclusions}

GI dysfunction in Duchenne muscular dystrophy has been sadly neglected as an issue affecting quality of life. ST mapping identified regional GI dysfunction in the $m d x$ dystrophic mouse. Dietary interventions to increase nitric oxide signaling in the GI tract reduced the number of colonic contractions and alleviated colonic constriction at rest. These findings in $m d x$ mice reveal that L-arginine can improve colonic motility and has potential therapeutic relevance for alleviating Gl discomfort, improving clinical care, and enhancing quality of life in Duchenne muscular dystrophy.

(J Neurogastroenterol Motil 2020;26:133-146)

\section{Key Words}

Arginine; Duchenne; Gastrointestinal diseases; Muscular dystrophy, Duchenne; Nitric oxide synthase type I, colon

Received: February 13, 2019 Revised: July 9, 2019 Accepted: July 23, 2019

(.) This is an Open Access article distributed under the terms of the Creative Commons Attribution Non-Commercial License (http://creativecommons. org/licenses/by-nc/4.0) which permits unrestricted non-commercial use, distribution, and reproduction in any medium, provided the original work is properly cited.

*Correspondence: Gordon S Lynch, PhD

Department of Physiology, The University of Melbourne, Building 181, Crn. Grattan St and Royal Pde, Parkville, VIC 3010, Australia Tel: +613-8344-0065, Fax: +613-8344-5818, E-mail: gsl@unimelb.edu.au 


\section{Introduction}

Duchenne muscular dystrophy (DMD) is a devastating muscle wasting disorder resulting from mutations in the dystrophin $(d m d)$ gene, characterized by progressive weakness and wasting of both skeletal and cardiac muscle, leading to loss of ambulation, respiratory complications, and death. As the $d m d$ gene encodes multiple dystrophin protein isoforms of varying length and tissue distributions, loss of dystrophin also affects other organ systems with serious impact on the patient quality of life. Perhaps the most neglected of all the problems experienced by DMD patients relates to gastrointestinal (GI) dysfunction. While much attention over the last 30 years has naturally focused on striated muscle defects in DMD, very little consideration has been paid to GI dysfunction and the abnormal gastric and colonic motor activities that cause persistent and debilitating discomfort, pain, malnutrition, and weight loss resulting from constipation, bloating, and reflux..$^{1-8}$ There is a significant unmet clinical need for novel therapeutics to combat GI dysfunction in DMD.

The dystrophin protein, particularly the full length Dp427 isoform, forms an integral component of a multimeric protein complex termed the dystrophin-glycoprotein complex (DGC). In striated muscle, the DGC comprises the $427 \mathrm{kDa}$ dystrophin protein in complex with the dystroglycans, dystrobrevins, and sarcoglycans, linking the actin cytoskeleton of the contractile apparatus to the extracellular matrix to ensure transmission of force across the muscle membrane. ${ }^{9,10}$ In addition to this integral mechanical role, components of the DGC including syntrophin, dystrobrevin, and notably neuronal nitric oxide synthase (nNOS, also known as NOS1), are implicated in signaling downstream of the DGC in striated muscle. ${ }^{11-18}$ NOS1 is localized to the sarcolemma of skeletal muscle fibers with the DGC. ${ }^{12}$ NOS1 produces nitric oxide (NO), a major endogenous mediator which in skeletal muscle, is released into the local circulation to cause vasodilation of the blood vessels, allowing for oxygenation. In DMD, sarcolemmal localization of NOS1 is lost, resulting in ischemia and damage to the muscle tissue. ${ }^{19}$ Thus, dystrophin and the DGC are key regulators of NOS1 localization and function. Forms of the DGC are expressed in the brain, and smooth muscle of the airways, ${ }^{20-22}$ but its exact role in these tissues is not well understood. The presence of a DGC in the enteric nervous system or smooth muscle of the GI system remains to be confirmed.

Studies in $m d x$ mice, the most commonly studied model of DMD, show evidence of altered GI motility and changes in constriction and contraction frequency relative to control mice. ${ }^{23-26} \mathrm{In}$ addition, fecal pellet production and fecal pellet mass are reduced in $m d x$ mice relative to control, ${ }^{27}$ and the muscularis externa of the colon is thicker in $m d x$ mice compared to control mice. ${ }^{28}$ Since dystrophin deficiency affects NOS1 localisation and NO production in skeletal muscle fibers, ${ }^{19}$ dysregulated NO production is similarly implicated in GI dysfunction with DMD. The reduced gastric and small intestinal motility in $m d x$ mice is counteracted by addition of relaxin, a modulator of $\mathrm{NO}$ production. ${ }^{29}$ Both myogenic NOS and endogenous $\mathrm{NO}$ production are defective in colons of $\mathrm{mdx}$ mice, ${ }^{25}$ and with exogenous administration of L-arginine, the main substrate for NO production by NOS1, is able to restore motor activity in isolated colons. ${ }^{30}$

Modulators of NO production have been tested for their ability to improve the dystrophic pathology in skeletal and cardiac muscle. Sildenafil, a phosphodiesterase type 5 inhibitor which modulates NO production, improves both diaphragm and heart structure and function in dystrophic mice. ${ }^{31-34}$ Additionally, L-arginine administration for 6 weeks improved dystrophic skeletal muscle pathology in the $m d x$ mouse, through restoration of NOS1 activity at the sarcolemma. ${ }^{35-40}$ Alternatively, administration of L-citrulline, a dietary amino acid which is converted to L-arginine and has higher bioavailability than L-arginine alone ${ }^{41}$ improves clinical scores in patients with Becker muscular dystrophy. ${ }^{42}$

Based on this evidence it is surprising that the effects of increasing NO production on GI function in vivo have not been examined. As compounds increasing NOS1 activity could improve GI function in muscular dystrophy and enhance quality of life for patients, we used video imaging and spatiotemporal (ST) mapping to interrogate GI dysfunction in $m d x$ mice and determine the therapeutic potential of dietary L-arginine or L-citrulline supplementation.

\section{Materials and Methods}

\section{Animals}

Animal experiments were performed in accordance with the Animal Research: Reporting of In Vivo Experiments (https://www. nc3rs.org.uk/arrive-guidelines). All experimental protocols were approved by the Animal Ethics Committee of The University of Melbourne (Approval No. AEC\#1513780) and conducted in accordance with the Australian code of practice for the care and use of animals for scientific purposes as stipulated by the National Health and Medical Research Council (Australia). Experiments were performed on 4-week-old and 12-week-old male C57Bl/10ScSn 
$(\mathrm{C} 57 \mathrm{BL} / 10)$ and C57BL/10ScSn-Dmd ${ }^{m d x} / \operatorname{Arc}(m d x)$ mice obtained from the Animal Resources Center (ARC Animal Facility, Murdoch, Western Australia). Mice arrived from the ARC at 3 or 11 weeks of age and were housed in boxes of 4-5 mice of the same genotype in microisolator cages on a 12 hour: 12 hour light:dark cycle with standard laboratory chow and water available ad libitum. All mice received a 1-week acclimation period prior to the beginning of experimental protocols and all protocols were performed in the light cycle.

\section{Fecal Pellet Analysis}

Following dissection and removal of the cecum, the oral end of the colon was attached to a cannula in a Sylgard lined organ bath, containing physiological saline at $35-37^{\circ} \mathrm{C}$ continuously superfused with Carbogen $\left(95 \% \mathrm{CO}_{2}, 5 \% \mathrm{O}_{2}\right)$. Gentle pressure was applied to flush fecal pellets from cannulated colons. Fecal pellets were then collected from the organ bath into clean weigh boats for assessment of wet weight, length, and width.

\section{Amino Acid Supplementation}

Four-week-old C57BL/10 and $m d x$ mice were administered L-alanine $(\mathrm{n}=12)$, L-citrulline $(\mathrm{n}=12)$, or L-arginine $(\mathrm{n}=12$; Sigma-Aldrich, St. Louis, MO, USA) via their food, a method that results in elevated concentrations of $\mathrm{L}$-citrulline and $\mathrm{L}$-arginine in plasma and skeletal muscle. ${ }^{43}$ Following a 1-week acclimation period during which mice received standard laboratory chow and water ad libitum, boxes of 4-5 mice were randomly allocated to receive a purified diet (AIN93G; Specialty Feeds, Glen Forrest, WA, Australia), supplemented with either $1 \% \mathrm{~L}$-alanine, L-citrulline or L-arginine for 8 weeks. Control mice received the purified diet without amino acid supplementation $(n=12)$. Based on the typical food consumption of $5 \mathrm{~g}$ of dry food per day for an about $25 \mathrm{~g}$ C57BL/10 mouse, this equated to a dose of about $1 \mathrm{~g} / \mathrm{kg} / \mathrm{day}$. It is important to note that dietary protein intake in mice is about 27.2 $\mathrm{g} / \mathrm{kg} / \mathrm{day}$, and the dose provided represents only about $3 \%$ higher amino acid intake.

\section{Video Recording of Colon Motility}

$\mathrm{C} 57 \mathrm{BL} / 10$ and $\mathrm{mdx}$ mice were sacrificed by cervical dislocation and the colon excised from the cecum to the rectum and placed into physiological saline $(118 \mathrm{mM} \mathrm{NaCl}, 4.6 \mathrm{mM} \mathrm{KCl}, 2.5 \mathrm{mM}$ $\mathrm{CaCl}_{2}, 1.2 \mathrm{mM} \mathrm{MgSO}, 1 \mathrm{mM} \mathrm{NaH} \mathrm{PO}_{4}, 25 \mathrm{mM} \mathrm{NaHCO}$, $11 \mathrm{mM}$ D-glucose). The cecum was removed, and the colon placed in a Sylgard lined organ bath, containing physiological saline at $35-37^{\circ} \mathrm{C}$ continuously superfused with Carbogen $\left(95 \% \mathrm{CO}_{2}\right.$,
$5 \% \mathrm{O}_{2}$ ) (Supplementary Fig. 1A). The colon was connected to an adjustable pressure head via oral and anal cannulas, as described previously. ${ }^{44}$ The oral end of the colon was connected to a reservoir of physiological saline, and the anal end to an outflow tube which provided a back pressure of 7-8 $\mathrm{cm} \mathrm{H}_{2} \mathrm{O}$. Prior to anal cannulation, pressure was applied from the oral reservoir to flush fecal contents from the colon. Once cannulated, an equilibration recording was taken $(2 \times 15$-minute videos), after which the luminal inflow was replaced with fresh physiological saline and contractions recorded at a controlled pressure over the period of 60 minutes $(4 \times 15$-minute videos). Following recordings of motility in physiological saline, contractions were recorded at a controlled pressure over a further 60 -minute period $(4 \times 15$-minute videos $)$ in the presence of 100 $\mu \mathrm{M}$ N-nitro-L-arginine (NOLA; Sigma Aldrich, St. Louis, MO, USA) in physiological saline to determine the effect of NOS1 inhibition on colonic motility.

A Logitech Quickcam Pro 9000 camera (Logitech, Lausanne, Switzerland) was placed above the organ bath and the video acquisition software VirtualDub 10.01 (Licensed under the GNU General Public License, developed by Avery Lee; www.virtualdub.org) used to acquire 15-minute video files of colonic contractile activity. After acquisition, .avi video files were converted into .su2 files using Scribble 2.1 (University of Melbourne in-house software), which uses an edge detection algorithm to identify colon diameter for each frame of the 15-minute video recording. The diameter of the colon at every point along its length is assigned a color, with constriction denoted warmer (red) colors and dilation assigned cooler (blue) colors. Each frame line is stacked with colon (gut) position shown on the $y$-axis and time across the $\mathrm{x}$-axis to generate a ST map. ST maps were visualized and analyzed in a purpose-built MATLAB plugin (Analyse2; University of Melbourne in-house software) via MATLAB (2014b; The MathWorks Inc, Natick, MA, USA). ST maps were analyzed for contraction number (Supplementary Fig. 1B; depicted as yellow/red streaks) and colon diameter at the level of the proximal, mid, and distal colon. Contraction refers to the spontaneous directional activity including colonic migrating motor complexes (CMMCs) and short contractions. Constriction and resting colon diameter refer to the instantaneous measure of colon diameter indicating dilation or constriction. Contraction numbers were measured by manually counting the number of yellow/red streaks per ST map. Using the analysis software (Analyse2) within MATLAB, colon diameter measures were made by drawing a horizontal line across the spatiotemporal map at the level of the proximal, mid, and distal colon and identifying the maximal (resting colon diameter) and minimal (constricted colon diameter) colon 
diameter during the 15 -minute recording as described previously. ${ }^{44}$ The color scale on all ST maps was kept constant to enable this comparison of the width of the colon.

\section{Western Immunoblotting}

Proximal, mid, and distal colon segments were snap frozen in Eppendorf tubes in liquid nitrogen and stored at $-80^{\circ} \mathrm{C}$. Lysis buffer $(50 \mathrm{mM}$ TrisHCl, $150 \mathrm{mM} \mathrm{NaCl}, 1 \mathrm{mM}$ EDTA, $1 \%$ (volume/ volume) Triton X-100, $2 \mathrm{mM} \mathrm{Na} \mathrm{VO}_{4}, 10 \mathrm{mM} \mathrm{NaF}, 1 \mu \mathrm{M}$ protease inhibitor cocktail) was added at a ratio of 10:1 buffer to tissue weight. Samples were minced with small scissors and homogenized using a PT 2100 Polytron (Kinematica, Switzerland) (15 second homogenization, 45 second intervals, repeated 3 times) on ice. Lysates were centrifuged $\left(10000 \mathrm{~g}, 4^{\circ} \mathrm{C}, 10\right.$ minutes) and protein concentration was determined using a DC Protein Assay (BioRad, Hercules, CA, USA), with lysates diluted to $1 \mathrm{mg} / \mathrm{mL}$ and $4 \times$ Laemmli sample buffer added to each sample. Samples were denatured $\left(95^{\circ} \mathrm{C}\right.$ for 3 minutes) and $15 \mu \mathrm{g}$ of total protein loaded onto 26-well Bio-Rad Criterion gels (4-15\%; Bio-Rad) alongside Precision Plus Protein Dual Color Standard (Bio-Rad). Gels were run at $100 \mathrm{~V}$ at room temperature and proteins were transferred to polyvinylidene difluoride (PVDF; Immobilon-P, Merck Millipore, Darmstadt, Germany) membranes via wet transfer at $100 \mathrm{~V}$ for 90 minutes in ice cold transfer buffer. Membranes were blocked in $1 \times$ Tris buffered saline with $0.1 \%$ Tween-20 (TBST)/5\% bovine serum albumin (BSA; Sigma Aldrich), followed by overnight incubation at $4^{\circ} \mathrm{C}$ in primary antibodies. Membranes were washed in TBST (3 $\times 5$ minutes), followed by 1 hour incubation at room temperature in secondary antibody and washed in TBST $(4 \times 10$ minutes). Membranes were developed using SuperSignal West Pico Chemiluminescent Substrate (Thermo Fisher Scientific, Waltham, MA, USA) on a ChemiDoc MP Imaging System (Bio-Rad). Total protein stains were completed using the BLOT-FastStain kit according to manufacturer's instructions (G-Biosciences, St. Louis, MO, USA) and quantification performed using Image Lab 4.1 software (Bio-Rad).

\section{Antibodies}

The following primary antibodies were used throughout the experiments in TBST/5\% BSA: mouse-anti-dystrophin MANEX1011B (clone 1C7) (deposited by Glenn E Morris; Developmental Studies Hybridoma Bank, The University of Iowa, Iowa City, IA, USA; $1: 1000$ ) and mouse- $\alpha-\beta$-dystroglycan (Leica Biosystems, Wetzlar, Germany; 1:5000). Horseradish peroxidaseconjugated sheep-anti-mouse IgG (GE Healthcare Life Sciences,
Marlborough, MA, USA) was used at 1:5000 in TBST/5\% BSA to detect dystrophin and 1:10000 in TBST/5\% BSA to detect $\beta$-dystroglycan.

\section{Nitric Oxide Synthase Activity Assay}

Proximal, mid, and distal colon segments were snap frozen in Eppendorf tubes in liquid nitrogen and stored at $-80^{\circ} \mathrm{C}$. NOS activity was measured using a colorimetric Nitric Oxide Synthase activity assay kit (\#ab211083; Abcam, Cambridge, UK) as per the manufacturers' instructions.

\section{Statistical Methods}

Data were analyzed between the 2 groups for the effect of genotype using Student's $t$ test or alternatively a Mann-Whitney $U$ test for contractile analyses. To determine differences between genotype and colon region, a 2-way ANOVA with Bonferroni's posthoc multiple comparisons test was used. Differences in contraction number between multiple treatment groups were assessed using a Kruskal-Wallis test. A $P$-value less than 0.05 was considered statistically significant. All statistical analyses were carried out using Prism Graphpad 6 software (GraphPad Software Inc, La Jolla, $\mathrm{CA}, \mathrm{USA})$. All values are mean \pm standard error of mean.

\section{Results}

\section{Oral Supplementation With L-arginine Restores Colon Motility in $m d x$ Mice}

Prior to initiating a dietary intervention, we first sought to confirm and characterize the GI phenotype in $m d x$ mice. Altered colonic motility has been reported in $m d x$ mice $e^{23-25,27,30}$ but specific regions of dysfunction had not been identified, especially using ST mapping. To confirm GI dysfunction in 4- and 12-week-old $\mathrm{mdx}$ mice, we measured fecal pellet length, width and weight, and frequency of colonic contractions using video imaging and ST mapping in colon preparations ex vivo. Fecal pellet length was increased (Fig. 1A) but width and weight were unchanged (Fig. 1B and 1C) in 4-week-old and 12-week-old $\mathrm{mdx}$ mice relative to $\mathrm{C} 57 \mathrm{BL} / 10$ control mice. The total number of colonic contractions, including short contractions in the distal region, over a 15-minute period was increased in both 4-week-old and 12-week-old $\mathrm{mdx}$ mice compared to $\mathrm{C} 57 \mathrm{BL} / 10$ mice (Fig. 1D and 1E). ST mapping revealed colonic dysfunction in 4-week-old and 12-week-old $\mathrm{mdx}$ mice, indicating GI impairments in the $m d x$ mice are apparent from weaning and do not develop progressively. 

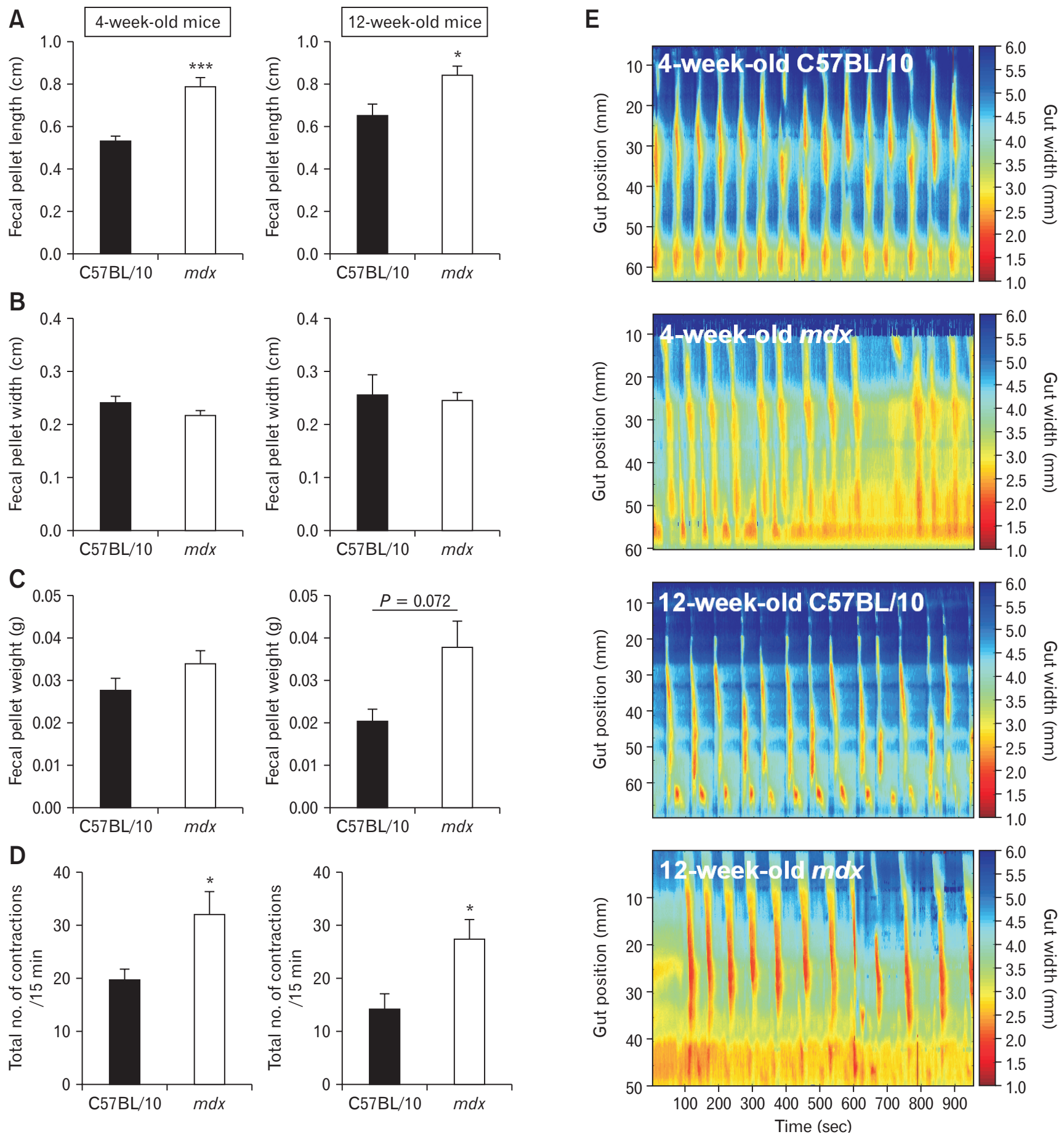

Figure 1. Gastrointestinal function is altered in 4-week-old and 12-week-old $m d x$ mice. To assess function, colons were excised from 4-weekold and 12-week-old male C57BL/10 and $m d x$ mice. Fecal pellets were flushed from each colon and assessed for length (A), width (B), and mass (C). Statistical analysis was performed using a Student's $t$ test. ${ }^{*} P<0.05$, ${ }^{* *} P<0.001$ compared to C57BL/10. $\mathrm{n}=6$-16/genotype/group. (D) Video imaging of total contraction number in colons from 4-week-old and 12-week-old C57BL/10 and mdx mice fed standard laboratory chow ad libitum. Representative spatiotemporal maps used to generate the data in (D) are shown in (E). Statistical analysis was performed using a MannWhitney $U$ test. ${ }^{*} P<0.05$ compared to $\mathrm{C} 57 \mathrm{BL} / 10$. n $=6$-16/genotype/group. 
After 8 weeks of oral amino acid supplementation no significant differences in colon length (Supplementary Fig. 2A), fecal pellet number (Supplementary Fig. 2B), length (Supplementary Fig. 2C), or fecal pellet width (Supplementary Fig. 2D) were observed between groups, except for a trend for $m d x$ mice to produce longer pellets than $\mathrm{C} 57 \mathrm{BL} / 10$ mice in the control diet group $(P=0.098$; Supplementary Fig. 2C), consistent with our findings in mice receiving standard laboratory chow (Fig. 1A). An overall main effect of diet was observed on fecal pellet weight (Supplementary Fig. 2E; $P<0.05$; diet main effect), but this was independent of genotype.

ST mapping of video recordings of colon contractions ex vivo revealed no difference in the number of orally-initiated CMMC contractions between C57BL/10 and $m d x$ mice (Fig. 2A and
2B). However, as the spatiotemporal maps indicated a complex contractile pattern in $m d x$ mice we next evaluated the number of contractions in the proximal, mid, and distal colon segments individually. No difference was observed in the number of contractions in the proximal colon (Fig. 2A and 2C) but the contraction number increased in the mid (Fig. 2A and 2D) and distal (Fig. 2A and $2 \mathrm{E}$ ) colons of $m d x$ mice on control and L-alanine supplemented diets relative to $\mathrm{C} 57 \mathrm{BL} / 10$ mice. Diet had no effect on contraction number in colons from C57BL/10 mice (data not shown), but administration of $\mathrm{L}$-arginine and $\mathrm{L}$-citrulline reduced the number of contractions in the mid (Fig. 2A and 2D) and distal colon segments in $m d x$ mice (Fig. 2A and 2E). We also measured resting colon diameter and constricted colon diameter from these video recordings
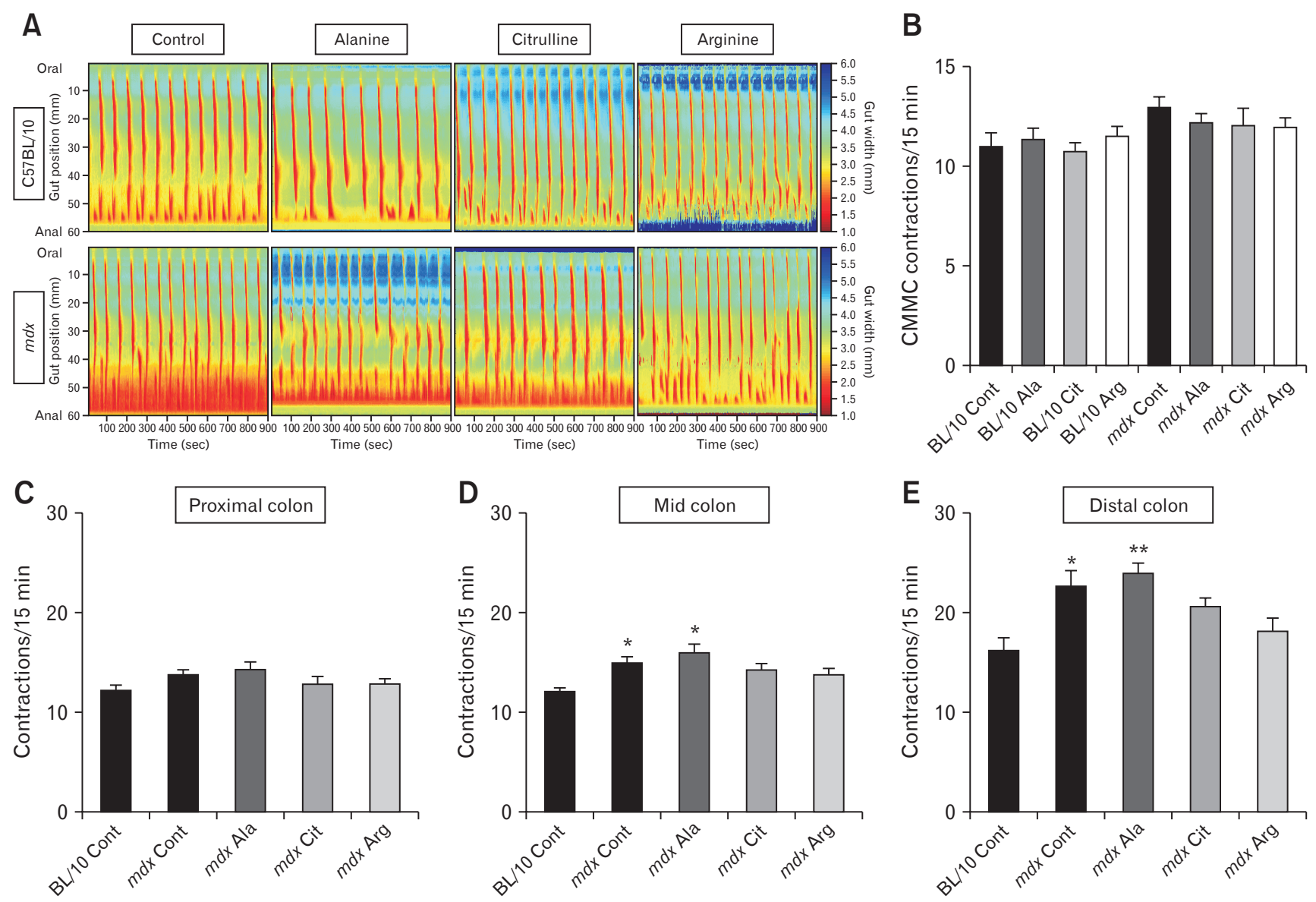

Figure 2. The distal colon of $m d x$ mice exhibits increased contraction frequency which is attenuated by administration of L-arginine (Arg) or Lcitrulline (Cit). Four-week-old male C57BL/10 and $m d x$ mice received either a control (Cont) diet or a diet supplemented with $1 \%$ L-alanine (Ala), L-citrulline, or L-arginine for 8 weeks. After treatment, colons were excised and contractions assessed ex vivo by video recording and ST mapping of colon diameter (A). The number of colonic migrating motor complexes (CMMCs; defined as contractions propagating more than half the length of the colon) were determined from the ST maps (B). Contraction frequency (number of contractions per 15-minute recording) was determined for the proximal colon (C), the mid colon (D), and the distal colon (E). Statistical analysis was performed using a Kruskal-Wallis test to assess effects of treatment. ${ }^{*} P<0.05,{ }^{* *} P<0.01$ relative to $\mathrm{C} 57 \mathrm{BL} / 10$ control, $\mathrm{n}=9-12 /$ genotype/group. 
A

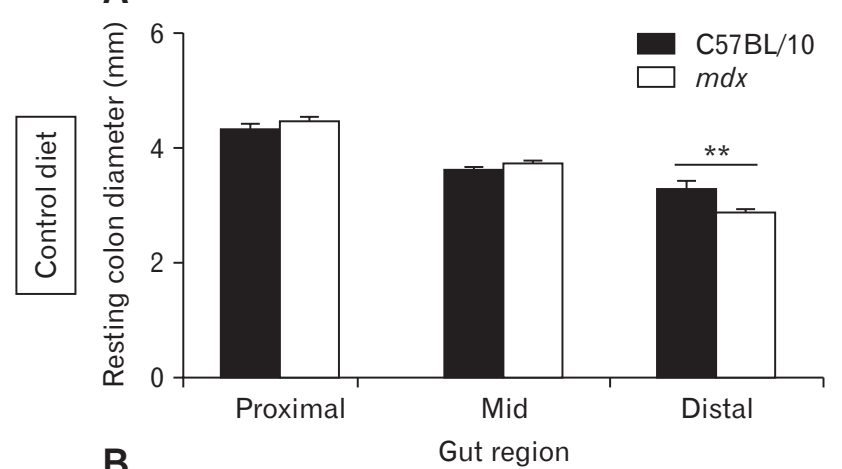

B
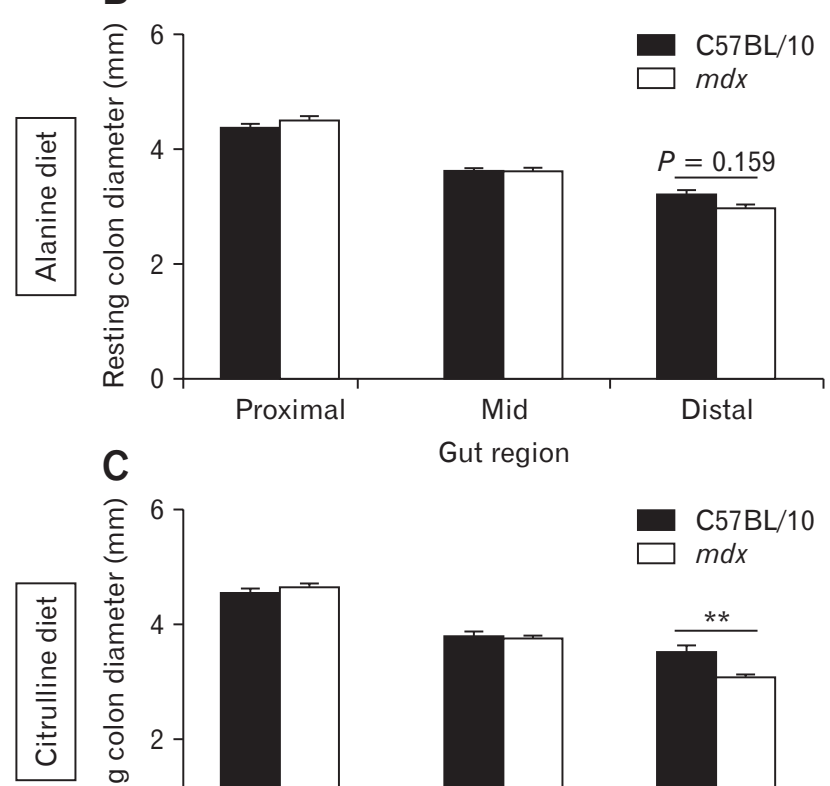

C

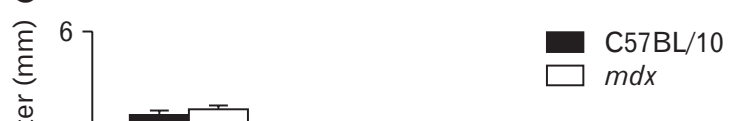

.

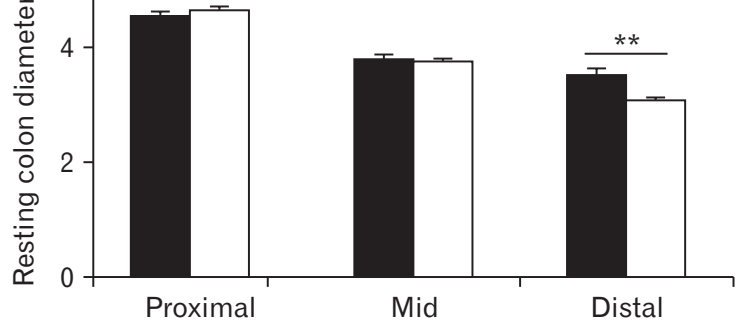

D

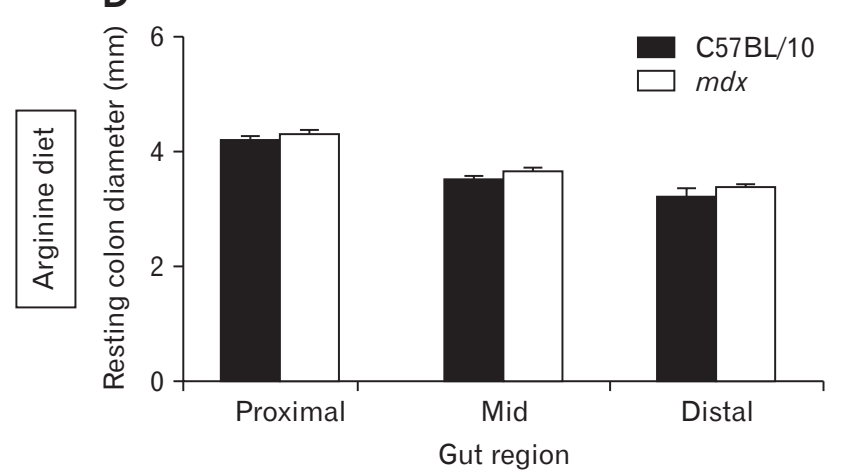

E

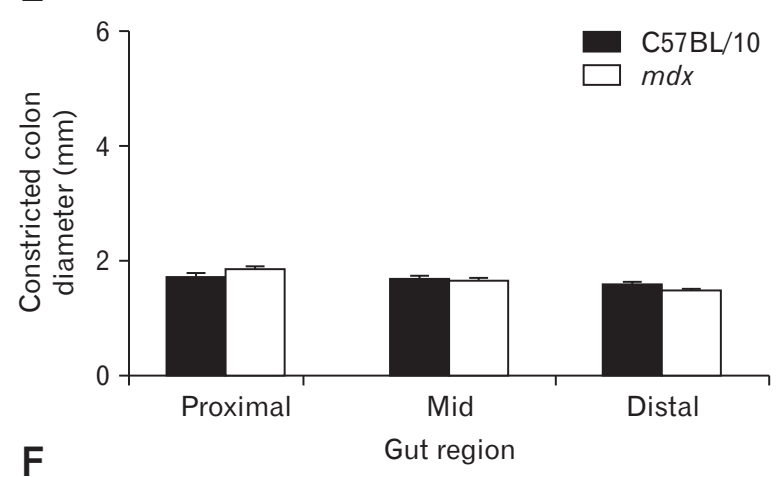

F

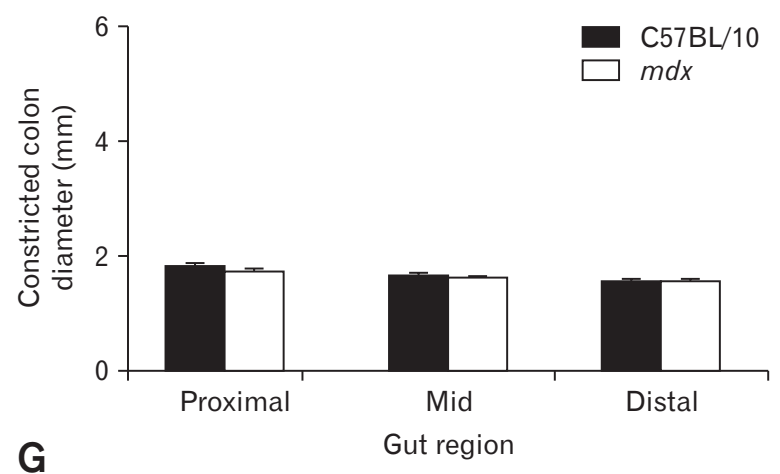

G

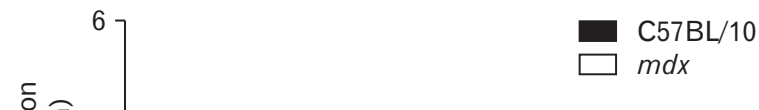

$\mathrm{C} 57 \mathrm{BL} / 10$

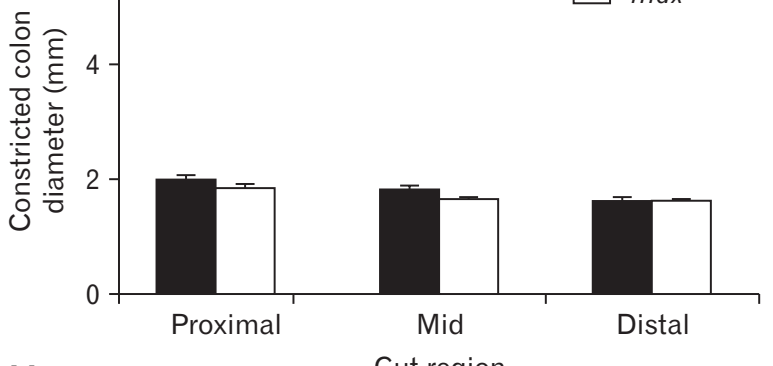

$\mathrm{H}$

Gut region
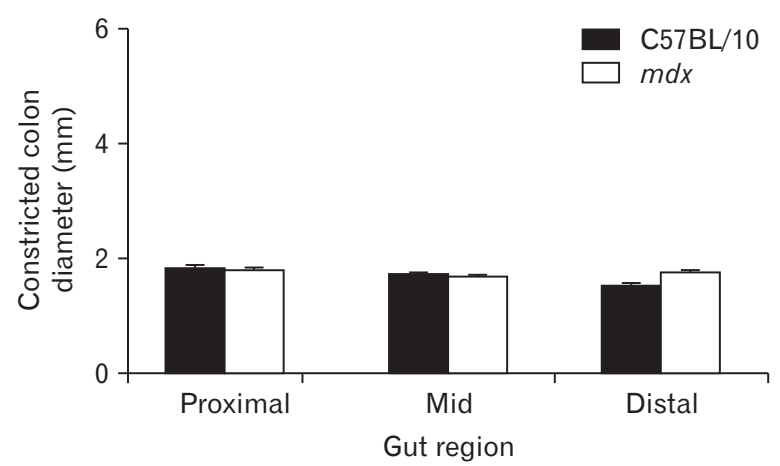

Figure 3. The distal colon of $m d x$ mice exhibits reduced diameter which is attenuated by administration of L-arginine. Resting colon diameter (mm) and constricted colon diameter $(\mathrm{mm})$ during the control recording period were measured for the proximal colon, the mid-colon, and the distal colon after video recording and spatiotemporal mapping of colons excised from $\mathrm{C} 57 \mathrm{BL} / 10$ and $\mathrm{mdx}$ mice receiving either the control diet (A, E) or a diet supplemented with $1 \%$ L-alanine $(\mathrm{B}, \mathrm{F}), \mathrm{L}$-citrulline $(\mathrm{C}, \mathrm{G})$, or L-arginine $(\mathrm{D}, \mathrm{H})$ respectively. Statistical analysis was performed using a 2-way ANOVA with a Bonferonni's post-hoc multiple comparisons test to determine the effects of genotype and colon region. ${ }^{* *} P<0.01$ relative to $\mathrm{C} 57 \mathrm{BL} / 10$ control; $\mathrm{n}=9-12 /$ genotype/group. 
in the proximal, mid, and distal colon. Resting diameter of the distal colon was reduced in the $m d x$ mice fed control $(P<0.01$; Fig. $3 \mathrm{~A})$ and L-citrulline $(P<0.01$; Fig. 3C) diets and trended towards being reduced on the $\mathrm{L}$-alanine $\operatorname{diet}(P=0.159$; Fig. $3 \mathrm{~B})$, compared with $\mathrm{C} 57 \mathrm{BL} / 10$ mice. There was no difference in the distal colon diameter between C57BL/10 and $m d x$ mice fed L-arginine (Fig. $3 \mathrm{D})$, indicating that administration of L-arginine attenuated the constriction in the $m d x$ mice distal colon. Constricted colon diameter was not different between $\mathrm{C} 57 \mathrm{BL} / 10$ and $m d x$ mice in any of the treatment groups (Fig. 3E-H). Analysis of contraction direction indicated no difference in the proportion of oral-initiated (type I), anal-initiated (type II), mid-colon initiated (type III) or simultaneous oral, and anal-initiated (type IV) contractions between colons from C57BL/10 or $m d x$ mice on any diet (Supplementary Fig. 3A-

A $+100 \mu \mathrm{M} N$-nitro-L-arginine
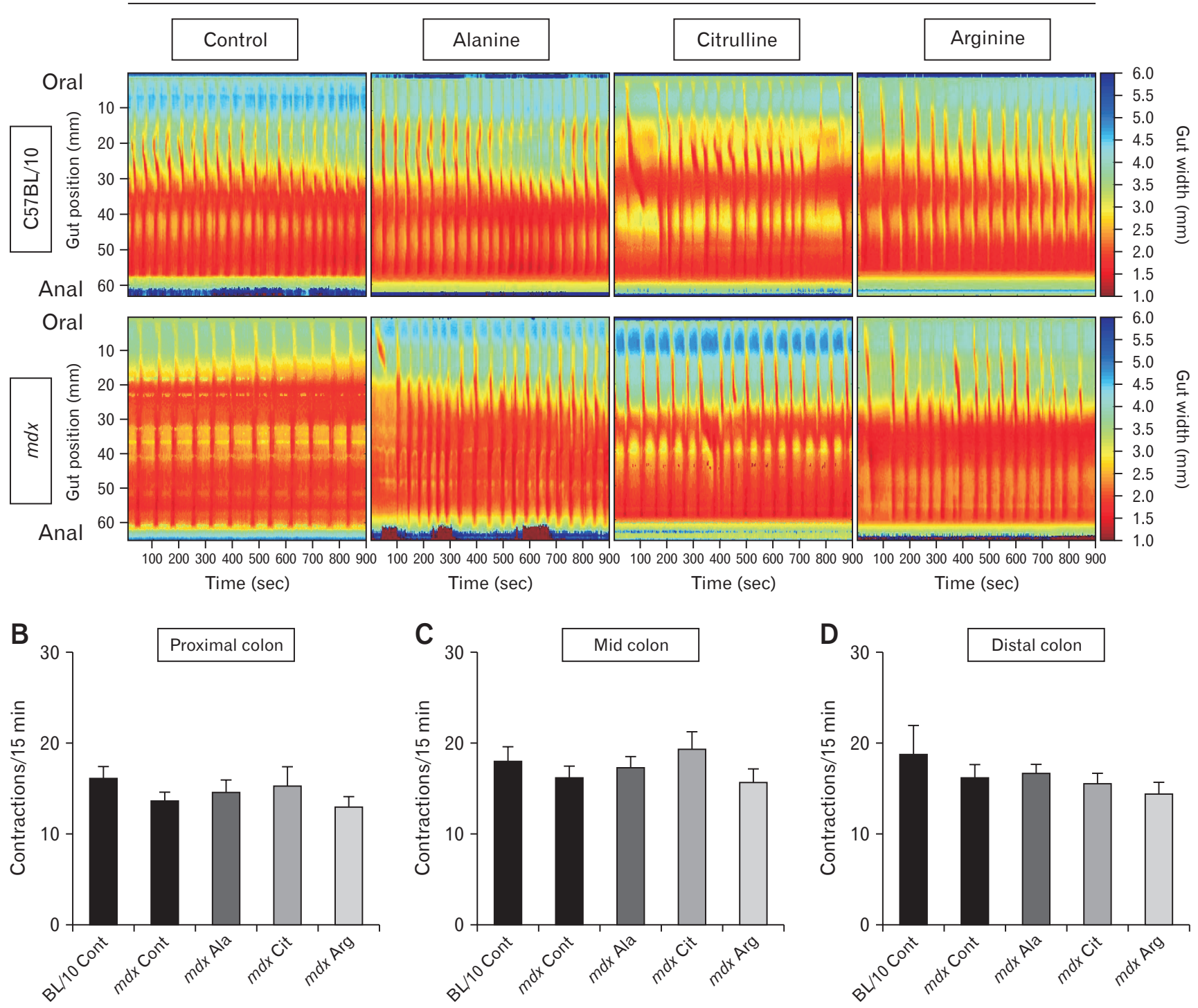

Figure 4. Inhibition of nitric oxide synthase (NOS) increases colonic contraction similarly in C57BL/10 and mdx mice. 4-week-old male $\mathrm{C} 57 \mathrm{BL} / 10$ and $m d x$ mice received either a control (Cont) diet or a diet supplemented with $1 \%$ L-alanine (Ala), L-citrulline (Cit), or L-arginine (Arg) for 8 weeks. After treatment, colons were excised, and contractions assessed ex vivo by video recording and spatiotemporal mapping of colon diameter in the presence of $100 \mu \mathrm{M}$ N-nitro-L-arginine (NOLA), a NOS inhibitor (A). Contraction frequency (number of contractions per 15-minute recording) was determined for the proximal colon (B), the mid colon (C), and the distal colon (D). Statistical analysis was performed using a Kruskal-Wallis test to determine the effect of treatment. $n=9-12 /$ genotype/group. 
A

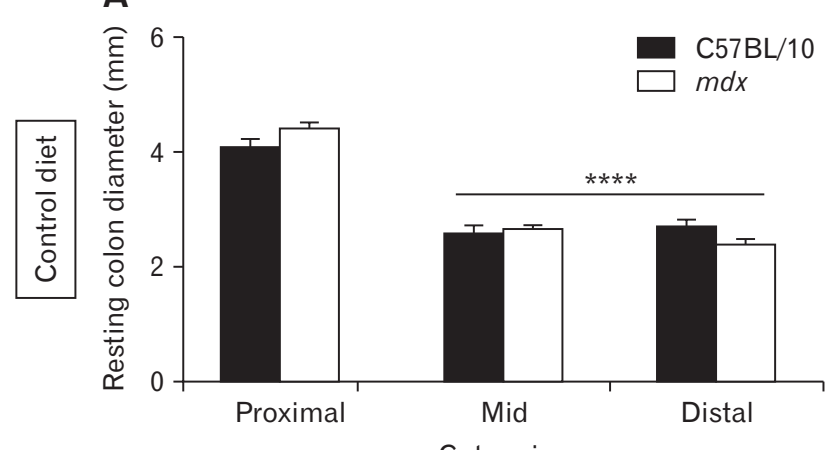

B

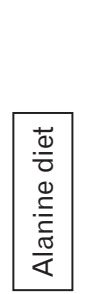

है

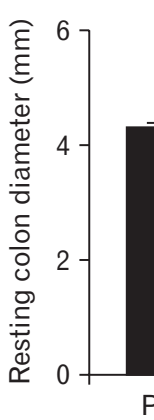

C

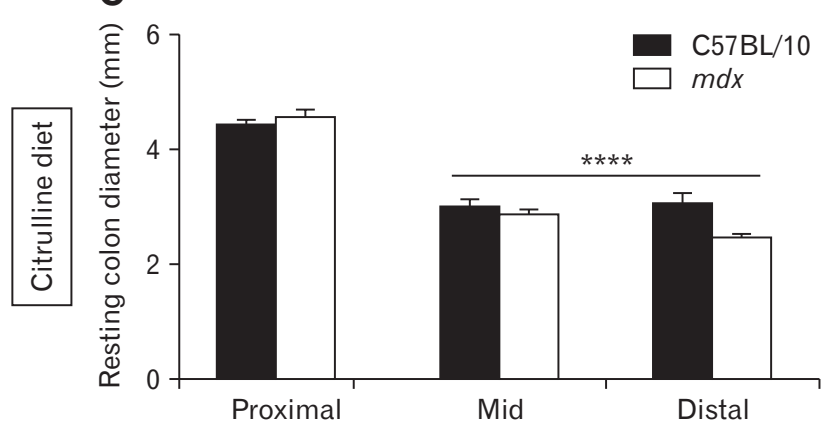

D

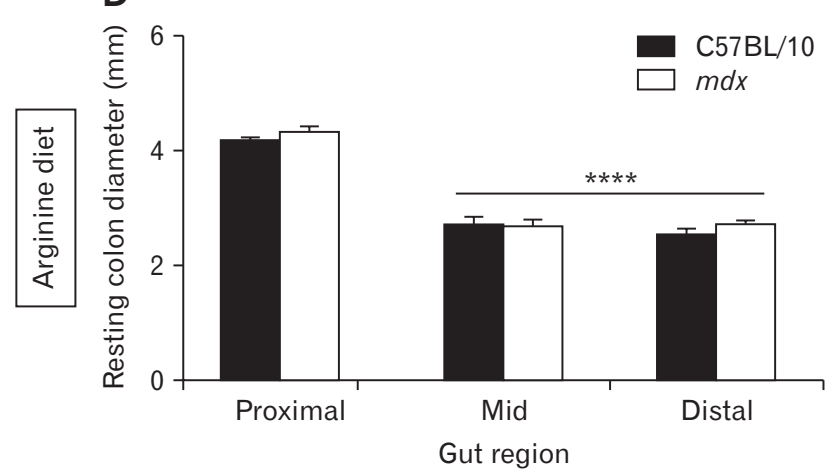

E

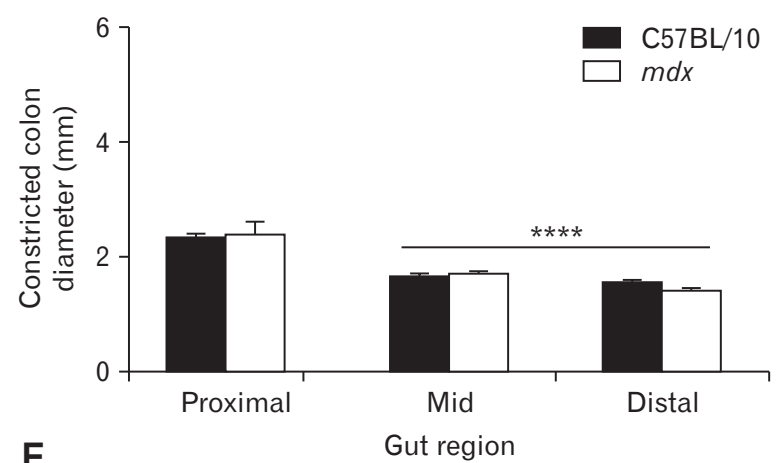

F
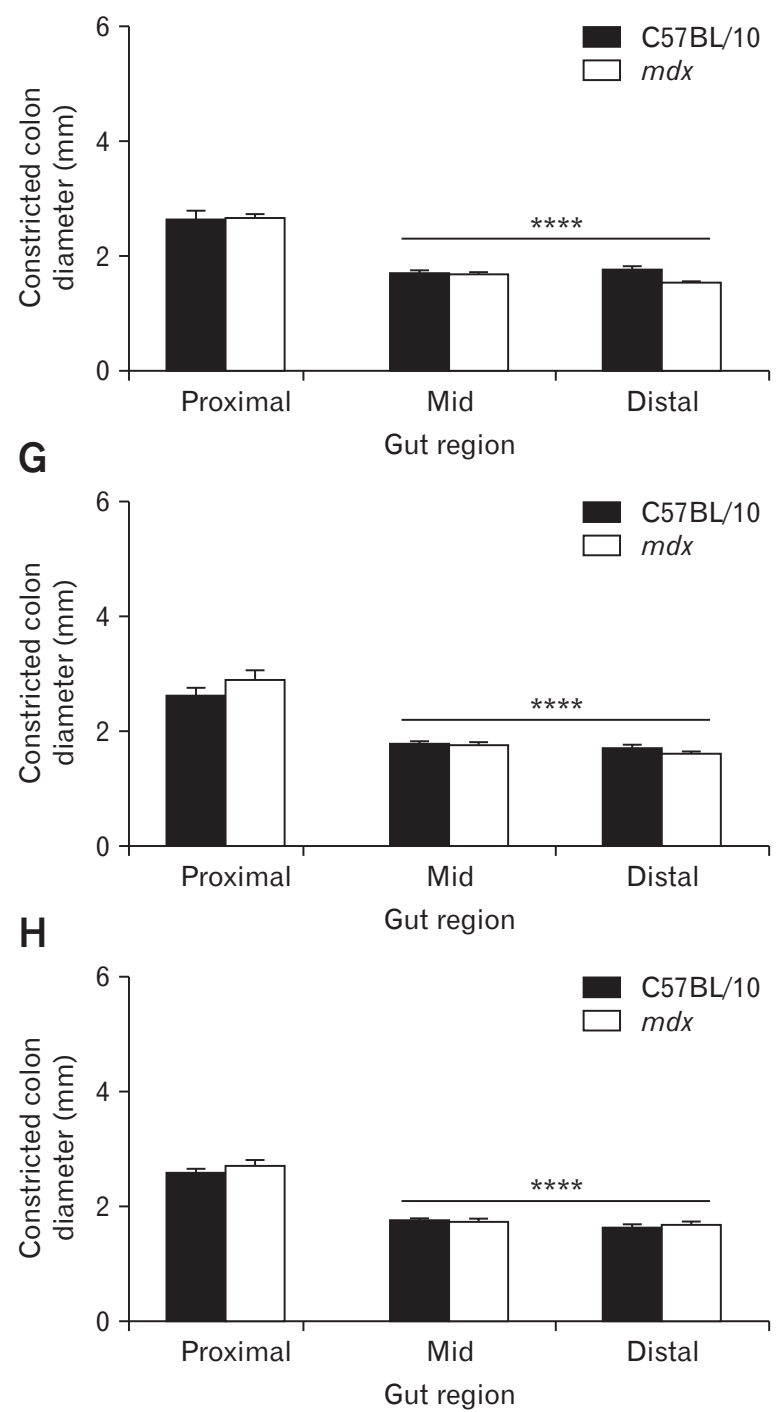

Figure 5. Inhibition of nitric oxide synthase (NOS) increases constriction to a similar extent in C57BL/10 and mdx mice. Resting colon diameter $(\mathrm{mm})$ and constricted colon diameter $(\mathrm{mm})$ in the presence of $100 \mu \mathrm{M} \mathrm{N}$-nitro-L-arginine (NOLA) were measured for the proximal colon, the mid colon, and the distal colon after video recording and spatiotemporal mapping of colons excised from C57BL/10 and $m d x$ mice receiving either the control diet (A, E) or a diet supplemented with $1 \%$ L-alanine (B, F), L-citrulline (C, G), or L-arginine (D, H). Statistical analysis was performed using a 2-way ANOVA with a Bonferonni's post-hoc multiple comparisons test to determine the effects of genotype and colon region. ${ }^{* * * *} P<0.0001$ colon region main effect; $\mathrm{n}=9-12$ /genotype/group. 
E). Together, these data suggest an altered phenotype within the distal colon of $m d x$ mice that may be ameliorated by L-arginine supplementation.

\section{Increased Constriction and Contractile Activity in $m d x$ Mice Are a Consequence of Reduced Nitric Oxide Signaling}

Altered GI contractile activity in the $m d x$ mouse has been

A

$\frac{\mathrm{C} 57 \mathrm{BL} / 10}{\frac{4 w k}{\mathrm{PMDPMD}} \frac{12 w k}{\mathrm{PMDPMD}}} \frac{m d x}{\frac{4 w k}{\text { PMDPMDPMDPMD }}}$
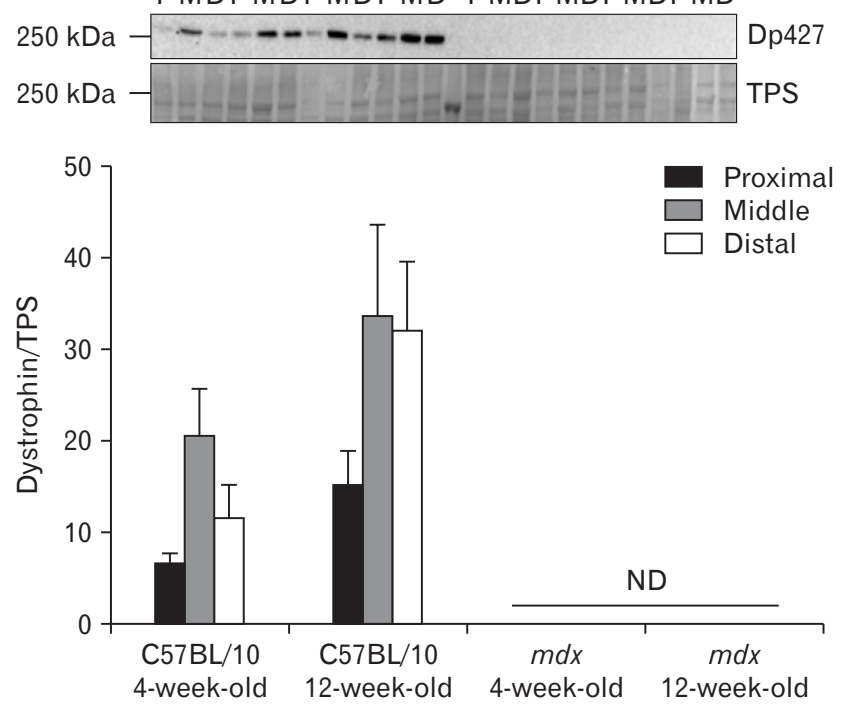

C

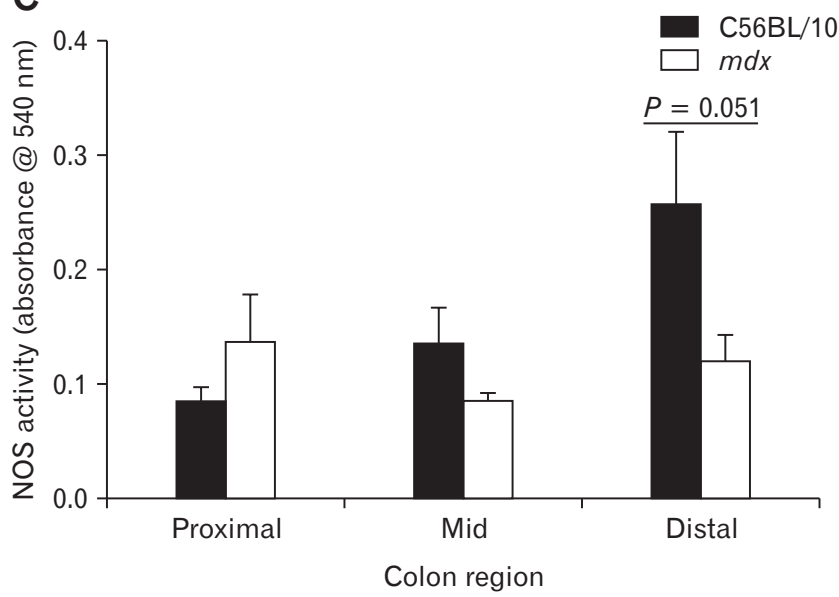

attributed to both impaired NO signaling ${ }^{25,30}$ and increased inflammation. ${ }^{28}$ To determine the contribution of $\mathrm{NO}$ signaling to the $m d x$ GI phenotype, $100 \mu \mathrm{M}$ NOLA (a NOS inhibitor) was added to the organ bath. ST mapping of video recordings of colon contractions ex vivo revealed no difference in contraction number in the proximal colon (Fig. 4A and 4B), mid (Fig. 4A and 4C), or distal (Fig. 4A and 4D) colons of $m d x$ mice on all diets relative to C57BL/10 mice. As expected, NOS inhibition increased contrac-

\section{B}
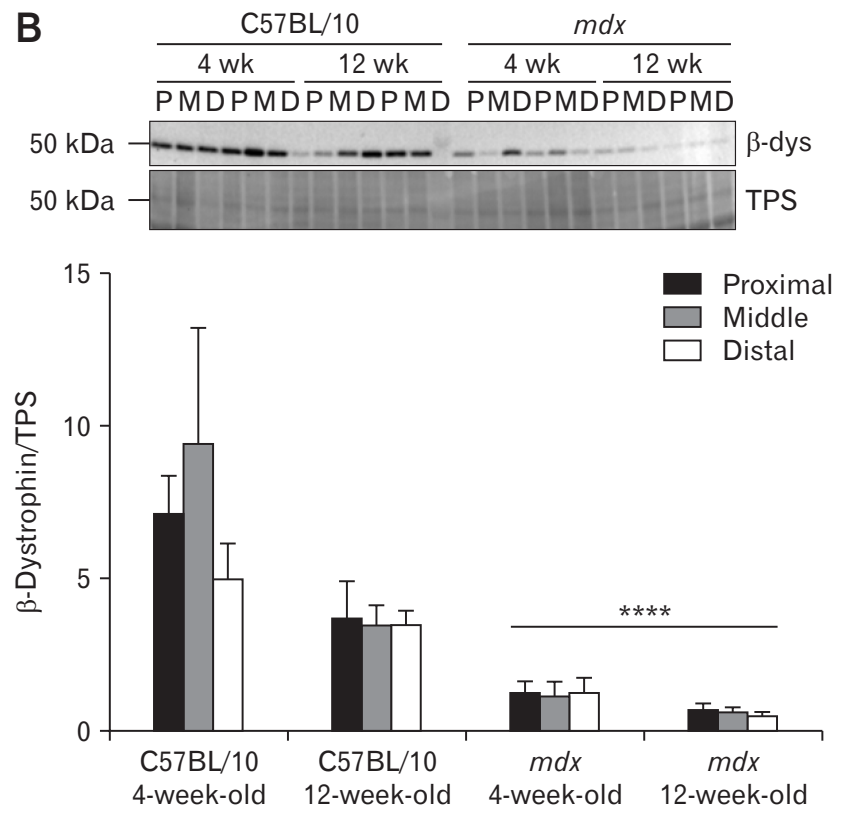

Figure 6. Colons from 12-week-old $m d x$ mice exhibit evidence of a disassembled dystrophin-glycoprotein complex (DGC) and reduced nitric oxide synthase (NOS) activity. Colons from 4-week-old and 12-week-old male C57BL/10 and mdx mice were cut into proximal (P), mid $(\mathrm{M})$, and distal (D) colon segments, lysed, and analyzed by Western immunoblotting for the expression of dystrophin (Dp427) protein (A) and $\beta$-dystroglycan protein ( $\beta$-dys; B). Protein expression was normalized to total protein content as assessed by a total protein stain (TPS). (C) NOS activity was measured in protein extracts from segments of proximal, mid, and distal colon from 12 -week-old C57BL/10 and $m d x$ mice using a colorimetric NOS activity assay. Statistical analysis was performed using a 2-way ANOVA with a Bonferonni's post-hoc multiple comparisons test to determine the effects of genotype and diet. ND, not detected. ${ }^{* * *} P<0.0001$ genotype main effect. $\mathrm{n}=4-6 /$ genotype/group. 
tion number in the $\mathrm{C} 57 \mathrm{BL} / 10$ colon in the proximal, mid, and distal segments by $24 \%, 32 \%$, and $13 \%$, respectively, relative to contraction number in physiological saline (Supplementary Fig. 4A), consistent with reduced NO signaling increasing colon motility. ${ }^{24,30}$ In contrast, NOS inhibition changed the contraction number by $-0.8 \%, 7 \%$, and $-40 \%$, respectively, in the proximal, mid, and distal segments of $m d x$ mice colon relative to contraction number in physiological saline, suggesting NOS inhibition had a reduced effect in colons from $m d x$ mice (Supplementary Fig. 4B). In addition, NOS inhibition reduced the resting and constricted diameter of the mid and distal regions of colons from $\mathrm{C} 57 \mathrm{BL} / 10$ and $\mathrm{mdx}$ mice relative to the proximal region for all diets tested (Fig. 5A-H; $P<0.0001$ region main effect). No difference in colon diameter was observed across the proximal, mid, and distal regions in $m d x$ mice relative to C57BL/10 mice in the presence of NOLA (Fig. 5A-H).

\section{Colons From mdx Mice Lack Dp427 Isoform Protein Expression and Have Reduced $\beta$-Dystroglycan Expression and Nitric Oxide Synthase Activity}

Although expression of the full length Dp427 kDa dystrophin protein has been reported in the interstitial cells of Cajal, enteric neurons, smooth muscle, and myoid cells of the gut by immunofluorescent studies, ${ }^{45}$ there remains a lack of knowledge regarding the function of dystrophin in these cells, particularly in relation to the presence of a DGC. By western immunoblotting, Dp427 expression was confirmed in proximal, mid, and distal colon segments from $\mathrm{C} 57 \mathrm{BL} / 10$ mice, and was absent in colon segments from $\mathrm{mdx}$ mice (Fig. 6A). Dp427 expression was lower in the proximal colon than in the mid colon (Fig 6A; $P<0.05$; region main effect), and higher in colon segments from 12-week-old mice than from 4-week-old mice (Fig 6A; $P<0.05$; age main effect). Expression of $\beta$-dystroglycan was confirmed in proximal, mid, and distal colon segments, with no significant difference in expression across the colon regions (Fig. 6B). Interestingly, $\beta$-dystroglycan expression was decreased in colon segments taken from $m d x$ mice relative to C57BL/10 mice $(P<0.0001$; Fig. 6B).

As the DGC localizes NOS1 to the sarcolemma and NOS1 inhibition increases the contraction number in the colon, we also examined NOS activity in the proximal, mid, and distal colon from C57BL/10 and $m d x$ mice. NOS activity showed a trend towards being increased in the distal colon of $\mathrm{C} 57 \mathrm{BL} / 10$ mice relative to the proximal and mid colon (Fig. $6 \mathrm{C} ; P=0.078$; region main effect). In $m d x$ mice, NOS activity was reduced in the distal colon compared to $\mathrm{C} 57 \mathrm{BL} / 10$ mice $(P=0.051$; Fig. 6C), correlating with our observations of reduced effectiveness of NOS inhibition in this gut region. Together, these data imply that loss of dystrophin in $m d x$ mice alters DGC expression in the colon and reduces NOS activity in the distal colon segment.

\section{Discussion}

GI dysfunction in DMD has been sadly neglected by researchers despite it being one of the most important clinical issues impacting quality of life for patients. Using ST mapping we identified regional GI dysfunction in the form of increased contractions in the distal colon in a murine model of DMD at both 4 and 12 weeks of age. Exogenous administration of L-arginine to isolated $\mathrm{mdx}$ mice colons has previously been shown to improve contractility in an organ bath in vitro. ${ }^{30}$ Here we showed that in vivo dietary interventions to increase NO signaling in the GI tract reduced the number of colonic contractions and alleviated distal colonic constriction under baseline conditions. These findings in $m d x$ mice show that dietary L-arginine supplementation can improve colonic motility have therapeutic relevance for DMD, with potential for alleviating GI discomfort, improving clinical care, and enhancing quality of life.

Although Dp427 expression has been identified in the mouse colon, ${ }^{45,46}$ no studies had shown a functional DGC in the colon. Western immunoblotting showed decreased protein expression of $\beta$-dystroglycan in colons of $m d x$ compared to $\mathrm{C} 57 \mathrm{BL} / 10$ mice. In striated muscle, the DGC fails to accumulate at the muscle membrane in the absence of Dp427, ${ }^{47}$ leading to reduced expression of $\beta$-dystroglycan and other DGC components because $\beta$-dystroglycan is phosphorylated and degraded by the proteasome when not bound to dystrophin. ${ }^{48,49}$ The reduced expression of $\beta$-dystroglycan in the colons of $m d x$ mice thus supports the presence of a functional DGC in the colon. While there are reports of DGC expression in airway smooth muscle, ${ }^{22}$ to our knowledge, this is the first evidence of a DGC in the colon. Although the DGC plays important structural and signaling roles in striated muscle, its role in the colon is unclear.

While exogenous administration of arginine has previously been shown to improve GI function in isolated distal colon segments in vitro, ${ }^{30}$ this is the first study to demonstrate that dietary supplementation with arginine, and to a lesser extent citrulline, can improve colon motility which has important therapeutic relevance to DMD patients. In the present study, dietary intervention was performed for a period of 8 weeks, since arginine $e^{35,38}$ and citrulline $e^{50}$ supplementation are under investigation for the treatment of skeletal muscle pathology in DMD, and are therefore likely to be admin- 
istered as chronic supplements. However, as acute in vitro arginine supplementation also improves the function of colons from $\mathrm{mdx}$ mice, ${ }^{30}$ it is unlikely that this long intervention period is required to elicit an effect. Whether improved colon function is maintained after removal of the dietary supplement remains to be determined.

While both citrulline and arginine supplementation reduced the contraction number in the distal colon of $m d x$ mice, only arginine supplementation alleviated abnormal distal colon constriction. These differences in the effectiveness of the 2 supplements are likely due to divergent inter-organ metabolism of arginine and citrul$\operatorname{line}^{51,52}$ and as a result, arginine bioavailability will be higher in the intestine in the arginine-fed mice compared with the citrulline-fed mice. Oral supplementation with citrulline is more efficient than arginine supplementation in increasing arginine availability in the circulation. ${ }^{53}$ Arginine is metabolized in the intestine, whereas enterocytes do not catabolize citrulline. Consequently, most of the citrulline that is orally administered, or produced in the intestine, will appear in the plasma, prior to being taken up by the kidneys and converted into arginine which is then released back in the circulation. $^{51,52}$

In the colon, $\mathrm{NO}$ both inhibits CMMC pacemaker activity ${ }^{54-56}$ (where NO inhibition results in increased contractile activity) and modulates mechanical tone ${ }^{25}$ (regulating constriction and dilation of the colon). NOS inhibition, through the exogenous administration of NOLA, increased the contraction number in colons from $\mathrm{C} 57 \mathrm{BL} / 10$ but not $\mathrm{mdx}$ mice, consistent with previous reports using L-NAME. ${ }^{25}$ These findings indicate that the increase in contraction number in $m d x$ mice colons under control conditions may result from reduced NO signaling. Restoration of NO signaling in the colon with dietary L-arginine improved colonic motility in $m d x$ mice. As the DGC is a known regulator of NOS1 activity in striated muscle, ${ }^{11,12,15}$ these data indicate that it may also play a signaling role through NOS1 in the colon to regulate motility.

Previous studies on colon dysfunction in $m d x$ mice focused on colon segments rather than intact, whole colons. ${ }^{23-25,30,45,57-59}$ Importantly, while analysis of whole colon motility showed no significant differences in the number or polarity of CMMC contractions between colons from $\mathrm{C} 57 \mathrm{BL} / 10$ and $\mathrm{mdx}$ mice, the present study highlights a dramatic increase in the number of short contractions in the distal colon of $m d x$ compared with control mice, consistent with previous studies focussing solely on the distal colon. ${ }^{23,30,59} \mathrm{In}$ terestingly, by western blot analysis we observed expression of both the dystrophin and $\beta$-dystroglycan protein along the length of the colon, suggesting the DGC is normally present along the entire length of the colon, therefore the absence of a phenotype in the proximal colon of $m d x$ mice was surprising. As we and others have demonstrated that the GI phenotype in $m d x$ mice is linked to dysregulated NO signaling, ${ }^{25,29,30,59}$ we hypothesize that the difference in phenotype between the proximal and distal colon may be due to alterations in the number of NOS1 positive neurons in each colon region. In support of this, we have previously observed the proportion of NOS1 positive neurons in the colon of $\mathrm{C} 57 \mathrm{BL} / 6$ mice to be higher in the distal region compared to the proximal and mid regions (Supplementary Fig. 5). The proportion of NOS1 positive neurons in $\mathrm{C} 57 \mathrm{BL} / 10$ and $m d x$ colons with or without amino acid supplementation was not assessed in the present study, so whether the number of NOS1 positive neurons in $\mathrm{mdx}$ mice colons is lower than in $\mathrm{C} 57 \mathrm{BL} / 10$ colons and whether arginine and/or citrulline administration alters this neuronal proportion, remains unknown. However, we showed NOS activity in C57BL/10 mice to be higher in the distal compared to the proximal and mid colons, whereas in $m d x$ mice, NOS activity remained similar across the proximal, mid, and distal colon. In conjunction with ST mapping showing a more severe phenotype in the distal colon segments of $m d x$ mice than the proximal and mid segments, this strongly implicates dystrophin and the DGC in the regulation of neuronal NOS1 signaling in the distal colon.

In summary, ST mapping identified regional GI dysfunction and increased contraction number in the colon of $m d x$ mice. Dietary interventions to increase $\mathrm{NO}$ signaling in the GI tract reduced the number of contractions produced by the colon ex vivo and alleviated abnormal colonic constriction at rest, demonstrating that in vivo dietary amino acid supplementation can improve GI function in $m d x$ mice. Dietary supplementation with L-arginine may be a simple intervention to improve colonic motility and GI discomfort in DMD patients that could improve clinical care and quality of life.

\section{Supplementary Materials}

Note: To access the supplementary figures mentioned in this article, visit the online version of Journal of Neurogastroenterology and Motility at http://www.jnmjournal.org/, and at https://doi. org/10.5056/jnm19029.

Acknowledgements: The authors thank Associate Professor Jess Nithianantharajah from The Florey Institute of Neuroscience and Mental Health, The University of Melbourne, Australia, for supplying $\mathrm{C} 57 \mathrm{BL} / 6$ mice. 
Financial support: This work was supported by research grants from the Stichting Duchenne Parent Project (Duchenne Parent Project Netherlands) to Gordon S Lynch.

\section{Conflicts of interest: None.}

Author contributions: Kristy Swiderski, Elisa L Hill-Yardin, René Koopman, Joel C Bornstein, and Gordon S Lynch designed the study; Kristy Swiderski, Rebecka Bindon, Jennifer Trieu, Shana Schokman, Anita J L Leembruggen, and Timur Naim performed the experimental work; René Koopman assisted with the nutritional intervention study; Elisa L Hill-Yardin, Mathusi Swaminathan, and Joel C Bornstein assisted with the setup and analysis of the video imaging experiments; Kristy Swiderski, Rebecka Bindon, Joel C Bornstein, and Gordon S Lynch analyzed the data; and Kristy Swiderski and Gordon S Lynch prepared the manuscript. All authors had the opportunity to comment on the manuscript.

\section{References}

1. Barohn RJ, Levine EJ, Olson JO, Mendell JR. Gastric hypomotility in Duchenne's muscular dystrophy. N Engl J Med 1988;319:15-18.

2. Bensen ES, Jaffe KM, Tarr PI. Acute gastric dilatation in Duchenne muscular dystrophy: a case report and review of the literature. Arch Phys Med Rehabil 1996;77:512-514.

3. Borrelli O, Salvia G, Mancini V, et al. Evolution of gastric electrical features and gastric emptying in children with Duchenne and Becker muscular dystrophy. Am J Gastroenterol 2005;100:695-702.

4. Dinan D, Levine MS, Gordon AR, Rubesin SE, Rombeau JL. Gastric wall weakening resulting in separate perforations in a patient with Duchenne's muscular dystrophy. AJR Am J Roentgenol 2003;181:807-808.

5. Okan M, Alper E, Cil E, Eralp O, Ağir H. Gastric emptying time in children with progressive muscular dystrophy. Turk J Pediatr 1997;39:6974.

6. Robin GC, de Falewski GL. Acute gastric dilatation in progressive muscular dystrophy. Lancet 1963;2:171-172.

7. Rönnblom A, Andersson S, Hellström PM, Danielsson A. Gastric emptying in myotonic dystrophy. Eur J Clin Invest 2002;32:570-574.

8. Stark P, Maves C, Wertz RA. Acute gastric dilatation as a manifestation of Duchenne's muscular dystrophy. Rofo 1988;149:554.

9. Ervasti JM, Campbell KP. A role for the dystrophin-glycoprotein complex as a transmembrane linker between laminin and actin. J Cell Biol 1993;122:809-823.

10. Ervasti JM, Campbell KP. Dystrophin-associated glycoproteins: their possible roles in the pathogenesis of Duchenne muscular dystrophy. Mol Cell Biol Hum Dis Ser 1993;3:139-166.

11. Allen DG, Whitehead NP, Froehner SC. Absence of dystrophin disrupts skeletal muscle signaling: roles of $\mathrm{Ca}^{2+}$, reactive oxygen species, and nitric oxide in the development of muscular dystrophy. Physiol Rev 2016;96:253-305.
12. Brenman JE, Chao DS, Xia H, Aldape K, Bredt DS. Nitric oxide synthase complexed with dystrophin and absent from skeletal muscle sarcolemma in Duchenne muscular dystrophy. Cell 1995;82:743-752.

13. Garbincius JF, Michele DE. Dystrophin-glycoprotein complex regulates muscle nitric oxide production through mechanoregulation of AMPK signaling. Proc Natl Acad Sci USA 2015;112:13663-13668.

14. Glass DJ. A signaling role for dystrophin: inhibiting skeletal muscle atrophy pathways. Cancer Cell 2005;8:351-352.

15. Grozdanovic Z, Baumgarten HG. Nitric oxide synthase in skeletal muscle fibers: a signaling component of the dystrophin-glycoprotein complex. Histol Histopathol 1999;14:243-256.

16. Judge LM, Arnett AL, Banks GB, Chamberlain JS. Expression of the dystrophin isoform Dp116 preserves functional muscle mass and extends lifespan without preventing dystrophy in severely dystrophic mice. Hum Mol Genet 2011;20:4978-4990.

17. Oak SA, Zhou YW, Jarrett HW. Skeletal muscle signaling pathway through the dystrophin glycoprotein complex and Rac1. J Biol Chem 2003;278:39287-39295.

18. Xiong Y, Zhou Y, Jarrett HW. Dystrophin glycoprotein complexassociated Gbetagamma subunits activate phosphatidylinositol-3-kinase/ Akt signaling in skeletal muscle in a laminin-dependent manner. J Cell Physiol 2009;219:402-414.

19. Lai Y, Thomas GD, Yue Y, et al. Dystrophins carrying spectrin-like repeats 16 and 17 anchor nNOS to the sarcolemma and enhance exercise performance in a mouse model of muscular dystrophy. $\mathrm{J}$ Clin Invest 2009;119:624-635.

20. Blake DJ, Hawkes R, Benson MA, Beesley PW. Different dystrophin-like complexes are expressed in neurons and glia. J Cell Biol 1999;147:645-658.

21. Gorecki DC, Derry JM, Barnard EA. Dystroglycan: brain localisation and chromosome mapping in the mouse. Hum Mol Genet 1994;3:15891597.

22. Sharma P, Tran T, Stelmack GL, et al. Expression of the dystrophinglycoprotein complex is a marker for human airway smooth muscle phenotype maturation. Am J Physiol Lung Cell Mol Physiol 2008;294:L57L68.

23. Mancinelli R, Tonali P, Servidei S, Azzena GB. Analysis of peristaltic reflex in young $m d x$ dystrophic mice. Neurosci Lett 1995;192:57-60.

24. Mulé F, D’Angelo S, Tabacchi G, Amato A, Serio R. Mechanical activity of small and large intestine in normal and $m d x$ mice: a comparative analysis. Neurogastroenterol Motil 1999;11:133-139.

25. Mulé F, Vannucchi MG, Corsani L, Serio R, Faussone-Pellegrini MS. Myogenic NOS and endogenous NO production are defective in colon from dystrophic $(m d x)$ mice. Am J Physiol Gastrointest Liver Physiol 2001;281:G1264-G1270.

26. Nearing M, Novak J, Partridge T. Greater colo-rectal activation phenotype in exercised $m d x$ mice. PLoS Curr Published Online First: 2 May 2018. doi: 10.1371/ currents.md.230ed3d6559b171e10279fc16e9ebef3.

27. Mulè F, Amato A, Serio R. Gastric emptying, small intestinal transit and fecal output in dystrophic (mdx) mice. J Physiol Sci 2010;60:75-79.

28. Manning J, Buckley MM, O’Halloran KD, O’Malley D. In vivo neutralization of IL-6 receptors ameliorates gastrointestinal dysfunction in 
dystrophin-deficient $m d x$ mice. Neurogastroenterol Motil 2016;28:10161026.

29. Vannucchi MG, Garella R, Cipriani G, Baccari MC. Relaxin counteracts the altered gastric motility of dystrophic $(\mathrm{mdx})$ mice: functional and immunohistochemical evidence for the involvement of nitric oxide. Am J Physiol Endocrinol Metab 2011;300:E380-E391.

30. Azzena GB, Mancinelli R. Nitric oxide regenerates the normal colonic peristaltic activity in $m d x$ dystrophic mouse. Neurosci Lett 1999;261:912.

31. Adamo CM, Dai DF, Percival JM, et al. Sildenafil reverses cardiac dysfunction in the $m d x$ mouse model of Duchenne muscular dystrophy. Proc Natl Acad Sci USA 2010;107:19079-19083.

32. Leung DG, Herzka DA, Thompson WR, et al. Sildenafil does not improve cardiomyopathy in Duchenne/Becker muscular dystrophy. Ann Neurol 2014;76:541-549.

33. Percival JM, Whitehead NP, Adams ME, Adamo CM, Beavo JA, Froehner SC. Sildenafil reduces respiratory muscle weakness and fibrosis in the $m d x$ mouse model of Duchenne muscular dystrophy. J Pathol 2012;228:77-87.

34. Witting N, Kruuse C, Nyhuus B, et al. Effect of sildenafil on skeletal and cardiac muscle in Becker muscular dystrophy. Ann Neurol 2014;76:550557.

35. Archer JD, Vargas CC, Anderson JE. Persistent and improved functional gain in $m d x$ dystrophic mice after treatment with $\mathrm{L}$-arginine and deflazacort. FASEB J 2006;20:738-740.

36. Barton ER, Morris L, Kawana M, Bish LT, Toursel T. Systemic administration of L-arginine benefits $m d x$ skeletal muscle function. Muscle Nerve 2005;32:751-760.

37. Chazalette D, Hnia K, Rivier F, Hugon G, Mornet D. $\alpha 7 \mathrm{~B}$ integrin changes in $m d x$ mouse muscles after L-arginine administration. FEBS Lett 2005;579:1079-1084.

38. Hnia K, Gayraud J, Hugon G, et al. L-arginine decreases inflammation and modulates the nuclear factor-kappaB/matrix metalloproteinase cascade in $m d x$ muscle fibers. AM J Pathol 2008;172:1509-1519.

39. Marques MJ, Barbin IC, Taniguti AP, Oggian DS, Ferretti R, Santo Neto H. Myocardial fibrosis is unaltered by long-term administration of L-arginine in dystrophin deficient $m d x$ mice: a histomorphometric analysis. Acta Biol Hung 2010;61:168-174.

40. Voisin V, Sébrié C, Matecki S, et al. L-arginine improves dystrophic phenotype in $m d x$ mice. Neurobiol Dis 2005;20:123-130.

41. Ham DJ, Kennedy TL, Caldow MK, Chee A, Lynch GS, Koopman R. Citrulline does not prevent skeletal muscle wasting or weakness in limbcasted mice. J Nutr 2015;145:900-906.

42. Hanff E, Hafner P, Bollenbach A, et al. Effects of single and combined metformin and L-citrulline supplementation on L-arginine-related pathways in Becker muscular dystrophy patients: possible biochemical and clinical implications. Amino Acids 2018;50:1391-1406.

43. Osowska S, Moinard C, Neveux N, Loï C, Cynober L. Citrulline in- creases arginine pools and restores nitrogen balance after massive intestinal resection. Gut 2004;53:1781-1786.

44. Swaminathan M, Hill-Yardin E, Ellis M, et al. Video imaging and spatiotemporal maps to analyze gastrointestinal motility in mice. J Vis Exp 2016:53828.

45. Vannucchi MG, Zardo C, Corsani L, Faussone-Pellegrini MS. Interstitial cells of Cajal, enteric neurons, and smooth muscle and myoid cells of the murine gastrointestinal tract express full-length dystrophin. Histochem Cell Biol 2002;118:449-457.

46. Vannucchi MG, Corsani L, Giovannini MG, Faussone-Pellegrini MS. Expression of dystrophin in the mouse myenteric neurones. Neurosci Lett 2001;300:120-124.

47. Ohlendieck K, Campbell KP. Dystrophin-associated proteins are greatly reduced in skeletal muscle from $m d x$ mice. J Cell Biol 1991;115:16851694.

48. Ilsley JL, Sudol M, Winder SJ. The interaction of dystrophin with beta-dystroglycan is regulated by tyrosine phosphorylation. Cell Signal 2001;13:625-632.

49. Miller G, Moore CJ, Terry R, et al. Preventing phosphorylation of dystroglycan ameliorates the dystrophic phenotype in $m d x$ mouse. HumMol Genet 2012;21:4508-4520.

50. Hafner P, Bonati U, Rubino D, et al. Treatment with L-citrulline and metformin in Duchenne muscular dystrophy: study protocol for a singlecentre, randomised, placebo-controlled trial. Trials 2016;17:389.

51. Bahri S, Zerrouk N, Aussel C, et al. Citrulline: from metabolism to therapeutic use. Nutrition 2013;29:479-484.

52. Moinard C, Cynober L. Citrulline: a new player in the control of nitrogen homeostasis. J Nutr 2007;137(6 suppl 2):1621S-1625S.

53. Agarwal U, Didelija IC, Yuan Y, Wang X, Marini JC. Supplemental citrulline is more efficient than arginine in increasing systemic arginine availability in mice. J Nutr 2017;147:596-602.

54. Fida R, Lyster DJ, Bywater RA, Taylor GS. Colonic migrating motor complexes (CMMCs) in the isolated mouse colon. Neurogastroenterol Motil 1997;9:99-107.

55. Powell AK, Bywater RA. Endogenous nitric oxide release modulates the direction and frequency of colonic migrating motor complexes in the isolated mouse colon. Neurogastroenterol Motil 2001;13:221-228.

56. Spencer NJ. Characteristics of colonic migrating motor complexes in neuronal NOS (nNOS) knockout mice. Front Neurosci 2013;7:184.

57. Mulè F, Serio R. Increased calcium influx is responsible for the sustained mechanical tone in colon from dystrophic $(\mathrm{mdx})$ mice. Gastroenterology 2001;120:1430-1437.

58. Serio R, Bonvissuto F, Mulè F. Altered electrical activity in colonic smooth muscle cells from dystrophic $(\mathrm{mdx})$ mice. Neurogastroenterol Motil 2001;13:169-175.

59. Tameyasu T, Ogura S, Ogihara K. The effect of e-, i-, and n-nitric oxide synthase inhibition on colonic motility in normal and muscular dystrophy (mdx) mice. Jpn J Physiol 2004;54:555-566. 